\title{
The Effectiveness of Three Types of Kindergarten Curricula in Promoting National Consciousness among the Jordanian Kindergarten Children
}

\author{
Mustafa F. AlKhawaldeh \\ Ali M. Ale'laimat \\ Assistant Professor \\ Department of Childhood Education \\ Hashemite University, Jordan \\ Nawaf S. Al-Zyoud \\ Mu'tasem M.al-Masa'deh \\ Assistant professor \\ Department of Special Education \\ Hashemite University, Jordan
}

\begin{abstract}
This study aimed to investigate the effectiveness of three types of kindergarten curricula in promoting national consciousness among Jordanian kindergarten children. The Ex post facto research design employed where a comparison was conducted between three types of kindergarten curricula on a sample of 120 children. A national test was used where it was found that there were statistically significant differences between respondents' national consciousness levels was attributed to the used curriculum while the modern comprehensive developmental curricula was the most effective curriculum for promoting national consciousness. Additionally, respondents who were enrolled in a kindergarten have higher national consciousness levels than those who did not enroll. It was found that there was no difference between respondents' national consciousness levels that can be attributed to their gender. Furthermore, there has been no difference between respondents' national consciousness levels which can be attributed to the interaction between respondents' gender and type of curriculum.
\end{abstract}

Keywords: Curriculum, Modern Developmental Curriculum, National Interactive Curriculum, Traditional Academic Curriculum, National Consciousness, Kindergarten, Jordan.

\section{Introduction}

Much attention has been given to children's education, which is attributed to its impact on children development and performance in several areas of life (Montaigne, 2013; Holt, 2017). Such attention has been paid as education of children participates in developing children's capabilities that reflects positively on developing society in various areas including economic, and social areas (Melhuish et al., 2015).

Therefore, children must be provided with much attention. Such attention must be provided starting from an early age. That shall positively affect the formation of individual's personality. It shall positively affect child's linguistics development and mental capabilities. It shall also participate in developing one's social skills and instilling ethical values within him. Thus, the early stage of childhood deserves much attention and care by educators, parents and researchers (Al-Khawaldeh, 2003).

Children in new world are considered as providers and receivers in the same time where they can effectively participate with their environment and evaluate their social world. National consciousness has been described by Fanon (1961) as 'the all-embracing crystallization of the innermost hopes of the whole people'. Thus, social studies regarding national consciousness concentrate on studying on national identity and national consciousness where children are active members in a variety of social contexts taking into account the geographical knowledge in early studies (Jahoda, 1963). 
Literature sees that school and kindergarten play a critical role in developing their knowledge and attitudes towards national consciousness (Banks and Roker, 1994).Kindergarten is the first educational institutions that the child is enrolled at. Therefore, a kindergarten must have a suitable environment that provides children with freedom, security, and assurance. Providing such environment shall facilitate children's growth and development in several areas including: psychological, cognitive, linguistic, social, emotional and spiritual are aswhich will prepare for the following educational phases.

Ministries of education should exert effort to develop kindergarten curricula. In addition, kindergarten teachers must adopt new teaching methods that can meet children's needs. Such methods should take into account the variation between students' abilities (Al-Nashef, 2004). Al-Momani, Hmaida, \& Haroon, 2012) suggest that most of the Jordanian kindergarten have not yet verified the type of curriculum that should be adopted. In Jordan, the curricula used in pre-school educational institutions fall into three types: the modern comprehensive developmental curriculum, the traditional academic curriculum, and the interactive national curriculum.

\section{Research Problem}

Several researchers have conducted studies regarding the impact of the type of the kindergarten curriculum on children's national consciousness and development. For instance, Al-Moomani et al. (2012) indicated that most of the kindergarten located in Jordan was not assured of the type of curriculum that should be adopted. They have also indicated that Jordanian kindergarten adopt inappropriate age curricula. For instance, their curricula adopt traditional teaching methods such as: repetition, learning by heart, and dictation. Moreover, their curricula adopt traditional assessment methods such as written tests. They indicated that curricula focus on academic skills with avoiding other non-academic skills. Thus, the research problem of the present study is represented in the following question: Does the type of the of kindergarten curriculum play an effective role in promoting national consciousness among Jordanian kindergarten children?

Thus, the present study aimed at exploring the impact of the of kindergarten curriculum on promoting national consciousness among Jordanian kindergarten children.

\section{Significance of the study}

The present study is significant theoretically and empirically. Its theoretical significance can be seen through providing information about the three types of curricula, providing future researchers with a theoretical framework when conducting similar studies. On the other hand, its empirical significance can be seen through providing researchers with an instrument for assessing the national consciousness level of kindergarten children. In addition, as the current study aimed at assessing the effectiveness of three types of educational curricula in promoting national consciousness among kindergarten children, it expected to participate in promoting loyalty among children.

\section{Limitations of the Study}

As the current study targets the children who are in kindergarten age, including those who attend the kindergarten and those who did not enroll in kindergarten, the present study was carried out in Jordanian kindergarten during the first semester of the academic year (2016-2017).

\section{Definition of terms}

Curriculum: Bhadr (2014: p.24) defines the concept (kindergarten curriculum) as "any book that a kindergarten introduces to its students to learn from". Ashoor \& Abu Al-Haija (2009: p.14) define the concept (kindergarten curriculum) as "a book that that a kindergarten introduces to its students". They also suggest that kindergarten curricula provide children with educational, cultural, social and sport experiences. These experiences are provided to children to modify their behavior and develop children in all areas.

The Traditional Academic Curriculum: Bhadr (2014: p.34) defines this expression as "a curriculum that adopts traditional teaching methods including using books and worksheets".

Interactive National Curriculum: Al-Zboon (2015: p.392) defines this expression as "the official curriculum of Jordanian kindergarten". It provides students with experiences. The board of the Jordanian Ministry of Education introduced an interactive national curriculum to develop pre-school children. 
The Modern Comprehensive Development Curriculum: Al-Hareeri (2015: p. 111) defines this expression as "a curriculum that involves a set of kindergarten experiences and activities that help children to grow, and modify their behaviors". They also promote interaction between them and the people surrounding them which will enable them to solve the difficulties or problems they face.

National consciousness (empirical definition): The researcher of the present study defines it as the information that enables one to solve problems, adhere to the laws, and have values.

\section{Theoretical Framework}

\subsection{Curricula}

Children are being given plenty of attention nowadays in several areas, and this attention has been given to children's educational institutions, including kindergarten. For instance, the Jordanian Ministry of Education has been providing much attention to kindergarten issues, difficulties and curricula. Kindergarten curricula should be consistent with the national vision. In addition, it must adopt modern teaching methods and keep up with the changes and contemporary developments. That should be achieved in order to develop children's talents, personalities, capabilities, and promoting their independence (Al-Arda, 2013).

The curricula used in Jordanian kindergarten fall into three types:

Firstly, the traditional curricula: Such curricula are used to develop children's abilities to remember and retrieve information. It aims to provide children with theoretical information about the things that can be perceived by their five senses and teach them three basic skills; reaching, writing and mathematical skills. These curricula focus on developing children's cognitive skills. However, it ignores other skills, such as the emotional and motor skills (Bhadr, 2014). These curricula are applied in private kindergarten designed by private publishing houses such as Dar-Al-Manhal, Dar Al-Rawwad and Al-Redwan.

Secondly, the Interactive National Curricula: the Jordanian Ministry of Education designed an interactive national curriculum for teaching the kindergarten children. The curriculum adopts modern teaching methods and principles where it was subsequently, provided with an activity book for children. In the first semester of the academic year (2007 -2008), Jordanian kindergarten started to use this curriculum (Al-Hasan, 2010). The age group targeted by this curriculum ranges between $(5-6)$ years old (Mhasees, 2008). In addition, the latest curriculum includes several units. The curriculum of the first semester includes the following units: me and my kindergarten, my family, and my animals. The curriculum of the second semester includes the following units: my nation, plants, water and my land.

Thirdly, the modern comprehensive development curriculum: This type of curriculum refers to any curriculum that provides kindergarten children with experiences inside and outside the kindergarten. Those experiences shall help children develop their personalities in accordance with pre-set educational goals. The latest curriculum involves the use of modern educational programs, such as "Montessori" and modern comprehensive development curricula including electronic curricula (Bhadr, 2014).

It is significant to promote national consciousness among kindergarten children. That can be achieved through informing them about the meaning of the relevant concepts and expressions. If this curriculum was taught to students efficiently, there shall be several benefits gained from it (Qandeel, 2003; Suleiman, 2010). In order to achieve the goals of the type of curriculum, an appropriate educational environment must be created for children. In addition, several educational requirements must be met. That shall enable children to grow in different areas (Abd-Al-al, 2005).

According to Atef (2002), kindergarten can promote national consciousness among children through the following methods:

- Promoting loyalty and love among children towards their country.

- Providing children with information about their national culture and concepts

- Raising their knowledge about their country's regulations.

- Encouraging children to respect their country's regulations.

- Promoting feelings of love towards national occasions, and encouraging children to participate in them.

- Teaching students in accordance with the adopted educational program and curricula. 


\section{Review of Literature}

The researcher of the present study reviewed several studies. Some of these studies concern the impact of attending kindergarten on the promotion of national consciousness among the Jordanian kindergarten children. Literature indicates that kindergarten and schools play an important role in promoting national consciousness in early life stage of life span (Miller, 1997) where childhood seen as the root of national consciousness. However, a little is known about the role of kindergarten in promoting the national consciousness among young children (Koh, 2010).

In a mixed backgrounds society, Dockett and Cusack (2003) found that Australian children in early childhood on age 5-8 years were able to deal the nationality complexities especially being half-Australian. Hengst (1997) concentrated in a comparative study on the dynamics in the construction of national identity in Turkey, Germany and Britain where children appeared more similar to other children from other nationalities than to same nationality adults.

Literature indicates that prompting national consciousness can be influenced by some factors. In Jordan, Hart (2002) carried out a study related to national consciousness and identity in al-Hussein Refugee Camp where he found that children's view of their national consciousness was overlapped with war, occupation, and hope of liberation of their homeland. This rises the importance of studying national consciousness with regards to young children where they show skill of language and experience social interactions.

Westheimer and Kahne (2004) indicated that there are three curriculums can be adopted to prompt national consciousness. Firstly, a curriculum aims to develop students' skills of hard work, obedience to laws, and honesty. Secondly, a curriculum that urges students to be active citizens through urging them to be involved communitybased organizations, religious associations, and political processes. Thirdly, a curriculum that assisted in creating a justice-oriented citizen who participate eliminate social inequality.

In his study to explore the role of school and family in promoting patriotism among children, Orabi (2010) found that school and family play a significant role in promoting patriotism among children where both play a significant role in educating children. Al-Mashrafi (2010) aimed to explore the effectiveness of a proposed educational program in promoting patriotism among orphan children. The sample consists from 42 male and female children. 24 children of them were males, whereas 18 were females. The ages of the sampled students are within the range of (4-7) years. In addition, the sample of the researcher includes 15 supervisors who work in an orphan house. The researcher used several instruments. For instance, he used a scale for assessing belonging, which it was given for pre-school children. In addition, supervisors were given an achievement test about the promotion of thorough education. It was found that the proposed educational program is effective in promoting patriotism among orphan children.

In another study, Abd Al-Wahab (2012) aimed to explore the impact of several proposed educational activities on the promotion of patriotism among the pre-school children. His sample consisted of 27 male and female children who were selected from the kindergarten located in Khartoum, Sudan ranging within $(5-6)$ years old. He developed a program for promoting patriotism consisted of 10-education activities and used patriotism assessment test. It was found that the proposed activities play an effective role in promoting patriotism among children.

Al-Khales and Abu Helo (2013) aimed to explore the way in which patriotism is promoted through education at the kindergarten located in Palestine. Furthermore, they also aimed to explore the attitudes of the kindergarten female teachers towards the promotion of patriotism through education at the kindergarten. A sample of 60 female kindergarten teachers was selected. Several instruments were used: an attitude scale for female teachers, semiarbitrated interview, and content analysis of the selected kindergarten curriculum. They found that female teachers have positive attitudes towards the promotion of patriotism among students. Through conducting interviews, they found that teachers do not promote patriotism much among students. Through conducting a content analysis, he found that kindergarten curricula do not promote patriotism among students.

Mohammad (2013) aimed at proposing a list of patriotic values that should be promoted among kindergarten children. Moreover, he aimed to identify the extent of promoting patriotism among kindergarten children in Saudi Arabia from the perspective of female teachers. His sample consisted of 30 female teachers who work at Al-Baha, Saudi Arabia. The researcher distributed questionnaire forms to the kindergarten female teachers. It was found that the curricula used in Saudi kindergarten promote patriotic values among children. It was found that such curricula aim at raising up good and loyal citizens. 
Al-Habeeb (2014) aimed at investigating Saudi teachers' attitudes towards the promotion of patriotism among kindergarten children in Saudi Arabia where a questionnaire was used for collecting data. It was found that their attitudes are positive.

Al-Samahhy (2014) aimed to explore the effectiveness of kindergarten education in promoting patriotism among kindergarten students in Egypt. Participants were selected from 100 public kindergarten located in Port-Saeed, Egypt. The sample was selected randomly and a descriptive approach was adopted. It was found that kindergarten education is effective in promoting patriotism among kindergarten students in Egypt.

It was found that there are several factors affecting the effectiveness of kindergarten education in promoting patriotism including the absence of a patriotic culture in kindergarten. Such factors also include the extent of addressing social concepts through kindergarten education.

\section{Method and procedures}

The current study aimed to explore the effectiveness of three types of kindergarten curricula in promoting national consciousness among Jordanian kindergarten children. (EX-Post Facto) method was employed. A comparison was conducted between three (3) types of kindergarten curricula in terms of their effectiveness in promoting national consciousness among Jordanian kindergarten children. These types are the modern comprehensive developmental curriculum, the traditional academic curriculum, and the interactive national curriculum. The sample consists of 120 female and male children who are enrolled in a kindergarten and children who arenot so. A comparison was conducted between four groups of children. These groups were:A group that consist from (KG2) students who use a modern comprehensive developmental curriculum.

A group that consist from (KG2) students who use an interactive curriculum.

A group that consist from (KG2) students who use a traditional curriculum (i.e. academic curriculum).

A group that consist from children who were not enrolled in kindergarten.

\subsection{Study population}

The study's population involves all the children enrolled at Jordanian private and public kindergarten during the academic year of (2016-2017). In addition, it involves all the children who unrolled at Jordanian kindergarten.

\subsection{Sample}

The sample was chosen from eightkindergarten which are: Montessori Kindergarten: 30 students who are being taught a modern comprehensive development curriculum were selected from Montessori Kindergarten. That AlNitaqain, and Marj Al-Fars kindergarten: 30 students who are being taught an interactive National curriculum were selected from That Al-Nitaqain, and Marj Al-Fars kindergarten. Al-Hijas private kindergarten: 30 students who are being taught an academic curriculum were selected from Al-Hijaz Private Kindergarten.

*The researcher selected 30 children who did not join the kindergarten. They were selected from the primary stage of several schools. These schools are: Safiya Bent Abd Al-Motaleb basic school, Al-Nozha basic school, Om-Al-Qotain mixed basis school, and Al-Ra'i School. Table (1) presents such information.

Table (1): Distribution of the sample according to the curriculum type, kindergarten / school type and gender

\begin{tabular}{|c|c|c|c|c|c|}
\hline \multirow[t]{2}{*}{ Curriculum } & \multirow[t]{2}{*}{ Kindergarten/ School } & \multirow{2}{*}{$\begin{array}{c}\text { Type of the } \\
\text { kindergarten }\end{array}$} & \multicolumn{2}{|c|}{ Gender } & \multirow[t]{2}{*}{ Total } \\
\hline & & & Male & Female & \\
\hline $\begin{array}{l}\text { Modern Comprehensive } \\
\text { Developmental }\end{array}$ & Modern Montessori & Private & 15 & 15 & 30 \\
\hline $\begin{array}{c}\text { Interactive } \\
\text { National }\end{array}$ & $\begin{array}{c}\text { That Al-Nitaqain and } \\
\text { Marj Al-Faras }\end{array}$ & Private & 15 & 15 & 30 \\
\hline Academic Curriculum & Al-Hijas Al-Ahliya & Private & 15 & 15 & 30 \\
\hline $\begin{array}{l}\text { Children who } \\
\text { did not join the } \\
\text { kindergarten }\end{array}$ & $\begin{array}{c}\text { Safiya Bent Abd- } \\
\text { Almotaleb, Al-Nozha, } \\
\text { Om Al-Qotain and Al- } \\
\text { Ra'i }\end{array}$ & $\begin{array}{l}\text { Private } \\
\text { and } \\
\text { public }\end{array}$ & 15 & 15 & 30 \\
\hline \multicolumn{3}{|c|}{ Total } & 60 & 60 & 120 \\
\hline
\end{tabular}




\subsection{Instrument}

The researcher used a test to measure the national consciousness level of respondents. That was achieved through reviewing the relevant theoretical literature and the tests that concern national consciousness. The test was designed based on the test designed by Qandeel and Mohammad (2012). It consists from multiple choice items. Some items are provided with three multiple choice answers and others are provided with three ones. The final version of the test consists from 24 items.

\subsection{Hypotheses}

To achieve the study's objectives, several hypotheses were proposed:

H0.1: There is no statistically significant difference - at the significance level of $(\alpha<0.05)$ - between the means of respondents which can be attributed to the curriculum type and enrollment in kindergarten

H0.2: There is no statistically significant difference- at the significance level of $(\alpha<0.05)$ - between the means of respondents which can be attributed to (gender and interaction between gender and type of curriculum).

\subsection{Analysis}

The collected data was processed and analyzed using the SPSS software. In addition, the following methods were used: Coder Richardson Equation (20) was used to calculate the value of the stability coefficient of the test. Means and standard deviations were calculated, one way ANOVA analysis was conducted, Scheffe test for the post-test was conducted, and ANCOVA analysis was conducted.

\section{Findings}

\subsection{First hypothesis}

H0.1: There is not any statistically significant difference - at the significance level of $(\alpha<0.05)$ - between the means of respondents which can be attributed to the curriculum type and enrollment in a kindergarten. To test the first hypothesis, means and standard deviations were calculated. In addition, one way ANOVA was conducted to identify the statistical significance of the differences between respondents' means which can be attributed to the type of the teaching curriculum and enrollment in a kindergarten.

Table 2 shows that students who were taught through using the modern comprehensive developmental curriculum show the highest performance with mean of 18.90. As for the students who were taught through using the traditional curriculum, they were ranked second. The students who were taught through using the Interactive National Curriculum were ranked second too. The mean of the two groups was 13.73. As for children who did not attend any kindergarten, they were ranked third with mean of 10.13 .

Table (2): The Means and Standard Deviations of the Children's Scores on the Achievement Test

\begin{tabular}{|l|c|c|c|}
\hline \multicolumn{1}{|c|}{ Type of the curriculum } & No. & Mean & Standard Deviation \\
\hline Modern Comprehensive Developmental & 30 & 18.90 & 4.10 \\
\hline Traditional Academic & 30 & 13.73 & 3.42 \\
\hline Interactive National & 30 & 13.73 & 3.92 \\
\hline Children who did not attend the kindergarten & 30 & 10.13 & 4.07 \\
\hline
\end{tabular}

Thus, the difference between children's means is for the favor of the ones who were taught through using the modern comprehensive developmental curriculum. In addition, the difference between children's means is for the favor of the ones who are enrolled in a kindergarten.

ANOVA univariate analysis was conducted to identify the statistical significance of the differences between children's means. The results of the analysis are presented in table (3).

Table (3): The Results of the univariate analysis

\begin{tabular}{|c|c|c|c|c|c|}
\hline $\begin{array}{c}\text { Source of the } \\
\text { variance }\end{array}$ & $\begin{array}{c}\text { Sum of the } \\
\text { squares }\end{array}$ & $\begin{array}{c}\text { Freedom } \\
\text { Degree }\end{array}$ & $\begin{array}{c}\text { Mean of the } \\
\text { Squares }\end{array}$ & $\begin{array}{c}\text { F Calculated } \\
\text { Value }\end{array}$ & Sig. \\
\hline Between the Groups & 1167.425 & 3 & 389.142 & 25.767 & 0.000 \\
\hline Inside the Groups & 1751.900 & 116 & 15.103 & & \\
\hline Total & 2919.325 & 119 & & & \\
\hline
\end{tabular}

(*): This sign means that the value is statistically significant at the statistical significance level of $(\alpha<0.05)$. 
Based on table (3), there is a statistically significant difference - at the statistical significance level of $(\mathrm{a}<0.05)-$ between the children's means which can be attributed to the type of curriculum. That is because the calculated value $\mathrm{F}$ is (25.767) and Sig. is (0.000).

Scheffe test was conducted. It was conducted to identify the statistical significance of the differences between the four groups. The results of the test indicate that there is a statistically significant difference between students' means which can be attributed to the curriculum. The results of Scheffe test indicate the following:

There is a difference between the means of the children who were taught through using a comprehensive developmental curriculum (18.90) and the ones who were taught through using a traditional curriculum (13.73). The difference is for the favor of the ones who were taught through using a comprehensive developmental curriculum.

There is a difference between the means of the children who were taught through using a comprehensive developmental curriculum (18.90) and the ones who were taught through using an interactive national curriculum (13.93). The difference is for the favor of the ones who were taught through using a comprehensive developmental curriculum.

There is a difference between the means of the children who were taught through using a comprehensive developmental curriculum (18.90) and the ones who did not join any kindergarten (10.13). The difference is for the favor of the ones who were taught through using a comprehensive developmental curriculum.

There is a difference between the means of the children who were taught through using a traditional academic curriculum (13.73) and the one who didn't join any kindergarten (10.3). The difference is for the favor of the ones who were taught through using a traditional academic curriculum.

There is a difference between the means of the children who study through using an interaction national curriculum (13.93) and the one who did not join any kindergarten (10.3). The difference is for the favor of the ones who were taught through using an interaction national curriculum.

It was found that there is a statistically significant difference between respondents' means which can be attributed to the type of curriculum. The difference is for the favor of the ones who study through using modern comprehensive curriculum.

\subsection{Second hypothesis}

H0.2: There is not any statistically significant difference - at the significance level of $(a<0.05)$ - between the means of respondents which can be attributed to (gender and interaction between gender and type of curriculum).

To test the second hypothesis, means and standard deviations were calculated. In addition, uni-variance analysis was conducted. It was found that there is a statistically significant difference between the means of the first three groups (i.e. the groups attending a kindergarten) which can be attributed to gender. The difference is for the favor of females. It was found that the there is a statistically significant difference between the respondents' means which can be attributed to enrollment in kindergarten. The difference is for the favor of the ones who are enrolled in a kindergarten. To explore the differences that can be attributed to the interaction between gender and the type of curriculum, ANCOVA analysis was conducted. The results of the analysis indicate that there is a statistically significant impact- at the statistical significance level of $(\alpha<0.05)$ - for the type of curriculum. That is because the calculated $F$ value is (25.016) and Sig. is less than 0.05.

The results of ANCOVA analysis indicate that gender does not have any statistically significant impact at the statistical significance level of $(\alpha<0.05)$. That is because the calculated $F$ value is $(0.451)$ and Sig. is higher than 0.05. The results of ANCOVA analysis also indicate that there is not any statistically significant differences between respondents' national consciousness levels which can be attributed to the interaction between respondents' gender and type of curriculum. That is because the calculated F value is (0.056) and Sig. is higher than 0.05 .

\section{Discussion}

Data analysis indicated that there is a statistically significant difference between the means of the kindergarten that attributed to their curriculum type that appeared to play a critical role in developing national consciousness (Zimmerman, 2002) although most of national consciousness, patriotism and national identity are rarely openly debated (Nash, 2005). 
This can be seen clearly a country like in Jordan that surrounded of political tensions of region. The difference is for the favor of the ones who study through using the modern comprehensive developmental curriculum. That means that the modern comprehensive developmental curriculum plays an effective role in promoting national consciousness among kindergarten children. That is because the curriculum enables children to grow and develop in several areas. It is also because the curriculum adopt several teaching means that suit kindergarten children. It appears that there is a need to have a strong link between education for citizenship national consciousness (Nash, 2005). The result is in line with the results found by Master et al. (2011). For instance, the researchers found that the developmental curriculum used in private kindergarten are better than the traditional curricula used in pubic kindergarten. However, the new curricula must have a clear and specific aims and methods to assist kindergarten students to participate effectively in their community through developing values of hard work, respect laws, and honesty (Westheimer and Kahne, 2004).

It was found that there is not any statistically significant difference between the means of respondents which can be attributed to gender. That indicates that there is not any statistically significant difference between the respondents' national consciousness levels which can be attributed to gender. That is can be explained by the fact that males and females are taught in the same manner within the classroom. Literature indicates that gender does not make any difference inshaping the national identity and national consciousness. This finding is in agreement with the results concluded by Al-Mashrafi (2010) For instance, the researcher found that there is not any statistically significant differences between respondents' patriotism levels which can be attributed to their gender. The researcher of the present study found that there is not any statistically significant difference between respondents' national consciousness levels which can be attributed to the interaction between respondents' gender and type of curriculum.

In the light of the aforementioned, it can be concluded that the type of curriculum significantly affects the promotion of national consciousness among female and male kindergarten childrenKhader (2002), Orabi (2010), and Abd Alwahab (2012) where schools, curriculum, and students play an important role in shaping national identity and national consciousness (Heathorn, 2000).

\section{Conclusion}

The researcher of the present study concluded the following: data analysis indicates that the comprehensive developmental curriculum plays an effective role in promoting national consciousness among kindergarten children. This should lead the Jordanian Ministry of Education and the administrations of private kindergarten to adopt comprehensive curriculums the prompt national identities and national consciousness. The children who are enrolled in private or public kindergarten show a better national consciousness level than the ones who are not enrolled in any kindergarten. This was explained by the fact that most of kindergarten in Jordan are ruled by private sector where services are expected to be better than public ones and thelevel and quality of services are higher. There was not any statistically significant differences between respondents' national consciousness levels which can be attributed to the interaction between respondents' gender and type of curriculum. This goes in line with several studies that found that gender did not influence developing national identity and national consciousness unlike other factors such as race and concentration was on the services that provided to those children (Koh, 2010). . Finally, the findings clearly indicated that there was not any statistically significant differences between respondents' national consciousness levels which can be attributed to gender. This was expected finding as the previous finding declined the effect of gender and curriculum on developing the national consciousness among the Jordanian kindergarten students.

\section{Recommendations}

In light of the aforementioned results, the researcher recommends the following: firstly, improving the kindergarten curricula by the Jordanian Ministry of Education in order to promote national consciousness among them. Secondly, meeting the needs of kindergarten children by the kindergarten administrations and teachers. Thirdly, provide students with more activities for kindergarten children that can promote national consciousness among them. Fourthly, making programs and holding seminars for female teachers. That should be achieved in the aim of promoting awareness among them about the way they should promote national consciousness among children. Finally, promoting awareness among parents about the importance of educational games and their role in promoting national consciousness among children. 


\section{References}

Abd-Alal, S. (2005). Role of the Kindergartens' Curriculum in Activating the Child's practicing his rights. Work paper introduced to the National Childhood Conference. Taz-Yemen.

Abd-Alwahab, Gh. (2012). Effect of Proposed Activities for Citizenship Development of the Pre-School Children. Faculty of Education. University of Al-Khartoum.

Al-Arda, M. (2013). The Child's Cognitive Development Pre-School. Its theories and Applications, Amman: Dar Al-Fikr.

Al-Habib, F. (2005). Citizenship Education: Contemporary Trends in Citizenship Education. Research introduced to the 13th forum for the Educational work leaders held in Al-Baha Region in K.S.A. Al-Marefa Journal, No. 120. King Saud University, Al-Riyadh- K.S.A.

Al-Hareeri, R. (2015). An Approach to the Child Education. Amman, Dar Al-Fikr.

Al-Hasan, S. (2010). Evaluating the Learning Environment in the Public Kindergarten and the First Three Grades Regarding the Material Environment, and the Teachers Knowledge's, Attitudes and Skills, and the Supervisors, and the First Grades, Curriculum, Amman, Ministry of Education.

Al-Khales, B. \& Ab-Helo, M. (2013). Reality of Teaching the Nation's Topic in the Kindergarten in Jerusalem City and the Female, Teachers Attitude toward teaching it. Al-Najah University Journal for Research's and Humanitarian Sciences, 27(11): 2329-2352.

Al-Khawaldeh, M. (2003). The Comprehensive Innovative Curriculum in Early Childhood Education. Amman. Dar Al-Maseera.

Al-Mashrafi, I. (2010). Effectiveness of Education Program on the Citizenship and Human Rights of the Orphan Child. Faculty of Education. Om-Al-Qora University.

Al-Momani, I., Hmaida, F. \& Haroon, R. (2012). Rejio, a Program in Early Childhood Education. Philosophy and the Educational Principles and implications. Dirasat Journal for Educational Sciences, 1(38): 23-26.

Al-Nashef. H. (2004). Kindergarten Programs. Amman: Dar Al-Fikr. Ministry of Education, "Department of Curriculum and the Textbooks" 2007, the Reference Book for the Kindergarten Female Teacher, AmmanJordan.

Al-Samahy, Z. (2014). Child rearing department, faculty of kindergarten, university of Port Said, Egypt. Journal of American Science, 10(9) 32-54.

Al-Zboon, I. (2015). Evaluating the Interactive National Curriculum and the General Frame Document and the General and specific outputs of the Hearing Impaired Kindergarten's Children from the Point of View of Their Female Children. Jordanian Journal in the Educational Sciences. 11(3), 387-402.

Ashoor, R. \& Abu Al-Haija, A. (2009). The Curriculum (Its Structure, Organization, Theories and its Scientific Applications). Amman: Dar Al-Janadriya.

Atef, H. (2002). Kindergarten Child's Integrated Activities, Cairo, Dar Al-Fikr Al-Arabi.

Banks, M. H. \&Roker. D. (1994). The Political Socialization of Youth: Exploring the Influence of School Experience. Journal of Adolescence 17: 3-15.

Bhader, S. (2014). Program for pre-school Children Education. Amman: Dar Al-Maseera.

Dockett, S. \& Cusack, M. (2003). Young Children's Views of Australia and Australians. Childhood Education, 79: 364-368.

Fanon, F. (1961). The Wretched of the Earth. Chapter 3: Pitfalls of national consciousness. Available from: http://www.marxists.org/subject/africa/fanon/pitfalls-national.htm. Retrieved on (9thSeptember 2018).

Hart, J. (2002). Children and Nationalism in a Palestinian Refugee Camp in Jordan. Childhood, 9 No. 1: 35-47.

Heathorn, S. (2000). For Home, Country, and Race: Gender, Class, and Englishness in the Elementary School, 1880-1914. Toronto: University of Toronto Press.

Hengst, H. (1997). Negotiating 'us' and 'Them': Children's Constructions of Collective Identity. Childhood 4 (1): 43-62.

Jahoda, G. (1963). The development of children's ideas about country and nationality.British Journal of Educational Psychology 33, 2: 143-153.

Khader, L. (2000). Role of Learning in Enhancing Belongness. Published Doctorate Dissertation, Cairo. Alam Al-Kotob.

Koh, S. S. (2010). National identity and young children: a comparative study of 4th and 5th graders in Singapore and the United States. PhD Thesis. University of Michigan.

Mahasees, S. (2008).Evaluating the Interactive National Curriculum Implemented for the Kindergarten Children in Jordan in light of the Global standards. Unpublished Doctorate Dissertation, University of Jordan, Amman- Jordan. 
Melhuish, E., Ereky-Stevens, K., Petrogiannis, K., Ariescu, A., Penderi, E., Rentzou, K., Tawell, A., Leseman, P. \& Broekhuisen, M. (2015). A Review of Research on the Effects of Early Childhood Education and Care on Child Development. CARE Project Report.

Miller, D. (1997). On Nationality. New York: Oxford University Press.

Mohammad, O. (2013). Analytical study of the values in the Saudi Kindergarten curriculum. The Specialized Educational International Journal, 20(3), 270-305.

Montaigne, M. (2013). Education of children. Theclassics Us.

Nash, M. (2005). How to Be Thankful for Being Free: Searching for a Convergence of Discourses on Teaching Patriotism, Citizenship, and United States History. The Teachers College Record, 107, 1: 214-240.

Orabi, M. (2010). Role of the Family in Citizenship Development and Citizenship in the children. Center of Islamic Research's and Studies- Cairo, Egypt.

Qandeel, M. \& Mohammad, D. (2010). Kindergarten Programs and Activities. Amman, Dar Al-Fikr.

Qnadeel, M. (2003). Curriculum's Basics in The Early Childhood, Amman, Dar Al-Fikr.

Suleiman, Sh. (2010). Religious and Social Education for the Children. Faculty of Kindergarten. Cairo University.

Westheimer, J. \& Kahne, J. (2004). What Kind of Citizen? The Politics of Educating for Democracy.American Educational Research Journal 41(2): 237-269.

Zimmerman, J. (2002). Whose America? Culture Wars in the Public Schools. Boston: Harvard University Press. 